sence of any well-defined or scientific course to be adopted pending the arrival of that stage when the cervix uteri will admit of the introduction of the hand for the purpose of effecting delivery. But before this stage the woman may perish.

We are, therefore, pleased to learn, that the question of the treatment of placenta prævia is shortly to be formally brought under the discussion of the profession, at the London Medical Society, by Dr. Barnes, whose well-known researches in placental pathology so well entitle him to be heard upon this subject.

\section{TESTIMONIAL TO SURGEONS IN THE CRIMEA.}

To the Editor of THE LANCET.

Srr,-As I think the medical profession will be gratified to know of the handsome conduct of the French towards one of our medical officers, I enclose copies of a letter and accompanying documents received from Mr. Wyatt, senior assistantsurgeon of the Coldstream Guards. It seems to me very desirable that the profession and the public should know, that though the services of our medical brethren in the Crimea are ignored and neglected by our own authorities, they are readily appreciated and acknowledged by our gallant and more generous allies. Wishing to publish this, while the interest about the terrible explosion is yet fresh in the public mind, I do not await the permission of my friend-the last man on earth to sound his own praises.

I am, Sir, your obedient servant,

Harley-street, December, $18 \overline{\text { s̆. }}$

HENRY HaNCOCK.

Camp, November 18th, 1855.

MY DEAR HANCOCK, - As I know it always gives you great pleasure to hear of anything gratifying to me, I write to tell you of a circumstance which has occurred to me, showing the generous feeling which actuates the French army with reference to the services of medical officers. The papers will have detailed to you the facts of the terrible and disastrous explosion which occurred in the French camp on the 15th. Being convinced that many casualties must have occurred to those who were in the vicinity of the explosion, which $I$ knew was near the large ambulance where some hundreds of French sick were then under treatment, I mounted my horse and rode on to the front, and, with Mr. Trotter, made our way to the French ambulance of the Second Division, and offered our services, as the wounded were being brought in in litters. I happened to have a previous acquaintance with the "Médecin en Chef," who availed himself gladly of any assistance at hand, and we had the pleasure of rendering some little service. The more pressing duties being over, we were invited to partake of their dinner, which we accepted, but from the violent succussion of the whole buildings all the crockery had been broke, and, worse still, the dinner savoured strongly of gunpowder; however, the remarks on all sides expressed $C e$ n'est que la guerre, and an additional bottle of Médoc appeased all. We returned to camp about ten P.M., feeling contented that we had gone to the help of our generous-hearted allies, and thought no more about it. However, yesterday, I received the enclosed communication from Dr. Hall, with the accompanying handsome tribute of thanks from the French head-quarters, which had been forwarded through our Commander-in-Chief. I am sure you will agree with me, that if the English Government were accustomed to estimate the medical profession in the army as the French do, there would not be the dissatisfaction that now pervades the ranks of the army medical officers. Kind regards. - Believe me, yours truly,

JOHN WYATT.

Head Quarters, Camp, Crimea, November 17th, 1855.

SIR, - . By the Commander-in-Chief's desire, I have the honour to forward the enclosed letter of thanks from the Intendant Général of the French army, to you and $\mathrm{Mr}$. Trotter, for your aid to the French wounded on the 15th instant. And in doing so, I beg to express to you and $\mathrm{Mr}$. Trotter the pleasure it gives me to be made the medium of communicating this gratifying tribute to your professional zeal and humanity. I have the honour to be, Sir, Your most obedient, humble servant,
Mon Generat, - II. I'Iutendant du deuxième corps d'armée me rend compte, qu'c̀ la suite de l'explosion du magasin poudre du parc d'artillerie, qui a eu lieu le 15 de ce mois, Messieurs John Wyatt et John William Trotter, médecins dans l'armée Anglaise, sont venus offrir avec empressement leurs soins à nos blessés. Je suis heureux, mon Général, d'avoir à porter à votre connaissance la conduite honorable de ces officiers de santé, et j'ai l'honneur de vous prier, de vouloir bien leur transmettre mes sincères rémerciments. Ce juste témoinage de gratitude aura pour eux bien plus de prix, en passant par votre intermédiare.

Je suis, avec respect, mon Général,

Votre très humble et très obeissant serviteur,

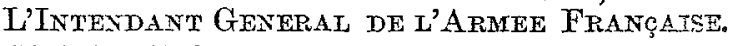
A Monsieur le Général en Chef

de l'Armée Anglaise.

\section{REMUNERATION OF MEDICAL OFFICERS IN THE EAST INDTA COMPANY'S SERVICE.}

To the Editor of The Lancet.

StR, - Considerable misapprehension existing as to the pay and allowances of medical officers in the service of the Fast India Company, I beg to offer trustworthy information on the subject.

The pay and allowances of an assistant-surgeon during the first two years of service are, free of all deductions, as nearly as possible, at a full batta station, 2245 ; at a half batta station, $£ 209$ per annum. After the expiration of two years of service-sometimes earlier, sometimes later-the assistantsurgeon is appointed to the charge of a native regiment, when his pay and allowances, free of deductions, are, at a full batta station, $£ 450$; at a half batta station, 2414 . Promotion to the rank of full surgeon occurs at the expiration of thirteen years' service as an assistant. The pay and allowances of a full surgeon, free of deductions, are, at a full batta station, about $£ 774$; at a half batta station, about $£ 721$ per annum.

Subscription to the funds, which is deducted monthly by the paymaster, is, in fact, a compulsory insurance-for the benefit of the officer's widow and orphans in the event of his death; for himself in the event of ill-health rendering necessary a return to England, as well as providing him an annuity of $£ 300$ at the expiration of twenty-two years' service. After fifteen years' service in India, the medical offcer can, under the new furlough regulations, return permanently to England on a pension of $£ 190$, increased in eight years by the annuity from the fund (provided that he has continued his subscription) to $£ 490$.

I wish it to be unclerstood that what I have stated above is to be looked upon as the minimum that a medical officer is likely to receive. Additional charges, such as those of a gaol, of the brigade or division staff, of commissariat and ordnance establishments, entitle the medical officer holding them to additional pay. In corroboration of my statement, I may mention that the senior assistant-surgeon at this station (of five years' service) is at present receiving, free of all deductions, pay and allowances equal to $£ 790$ per annum. Life in India is undoubtedly monotonous, but to a man of simple tastes and studious habits may not be an undesirable mode of existence.

I am, Sir, your most obedient servant,

Bengal, sept. 22nd, 1855. A Bengal Assistant-SUrgeon.

\section{THE ASSISTANT-SURGEONS' PETITION}

THE following is the reply of Lord Panmure to the late memorial of the army assistant-surgeons in the Crimea:[COPY.]

War Department, Oct. 30.

SIR, - I am desired by Lord Panmure to convey to you his Lordship's views on the memorial recently submitted by the assistant-surgeons of the army in the Crimea, and to request that you will adopt such measures as you may see fit, to cause these views to be made known to the memorialists.

Lord Panmure cannot but remark that very few of the signatures attached to the memorial represent individuals who have had more than two and a quarter years' experience in the service-a large proportion much less time-when they thus combined to criticise its alleged defects, and suggest 591 
improvements in its organization. Fully admitting, however, that any memorial, emanating from officers, and respectfully worded, has a claim to be received and answered with courtesy, his Lordship will only remark, that it would have carried more weight with him if signed by officers of more experience; but this opinion has not impeded Lord Panmure's careful examination of the complaint. The memorialists represent the insufficiency of the present emoluments and relative rank of assistant-surgeons. The pay of an assistant-surgeon, on first appointment, is that of a first lieutenant after seven years' service. The rank is also that of a first lieutenant. Lord Panmure cannot admit that the above rate of military pay is too low, accompanied as it is by proportionate retirement to halfpay, with a claim to pension to widows, and compassionate allow ances for children in cases of death. His Lordship is quite prepared to admit that it will not bear comparison with the emoluments of many of the profession whose practice is in populous neighbourhoods; but these are rarely men just entering the profession; nor must it be forgotten that thousands of the medical profession, of high abilities and acqnirements, less fortunately circumstanced, wear out their best energies in gaining a smaller and more precarious income than the pay and advantages of an assistant-surgeon, and no provision from the public in case of their superannuation or death. With regard to time of service before the higher rate of $10 \mathrm{~s}$. is attained, Lord Panmure is of opinion that the present regulation, requiring ten years, may be a fair subject for reconsideration hereafter; but his Lordship is not aware that this, or any of the present considerations of service, have been the means of keeping medical men of talent and proficiency out of the army, as stated by the memorialists. The allegation that the smallness of the medical officer's pay prevents his association with his brother officers, Lord Parmure cannot but regard as unfounded, the more so as the medical officer is confessedly at less expense than the combatant officer for uniforms and some other charges; and with reference to the memorialists' remark, that they receive their appointments only after a long and expensive term of professional study, and not until they have first arrived at the age of twenty-one, whereas the executive officer may, without any preliminary education, join the army at a very early age, Lord Panmure observes, that all officers are subjected to examination to ascertain their preliminary education, which, in the case of a large number, is also an expensive one; nor will the examination be confined to the first commission, when circumstances permit a general application of the existing regulations on the subject. First appointments at very early age are the exception, not the rule; and the limit of age for commissions has been advanced since the commencement of the war. Lord Panmure cannot draw, from the more rapid promotion of the execntive than the medical officers, any grounds for the conclusion that it implies an undeservedly low estimate of the exertions of the latter. It implies only that the casualties of war affect the combatant more than the non-combatant class of officers; the promotion that does take place appears to Lord Panmure to be distributed with fairness; that it is slow only proves that the danger of battle, privation, and climate, are not so fatal as the memorialists would infer. Lord Panmure has received but few complaints from those whose length of service gives them a better right to expect promotion than can be pleaded by gentlemen of from six months' to two years' service only. With reference to the complaint of the inferior character of some of the duties that now fall to the junior medical officers, the memorialists should be informed that this ground of complaint is under consideration. Lord Panmure cannot, however, relax the principle which requires that the assistant-surgeons in military hospitals be prepared to do any duties, even those of dispenser, dresser, or clerk, which may be required of them by their professional superiors.

With reference to leave for professional improvement and other purposes, Lord Panmure can only remark that when leave can be properly granted, it is not withheld. Leave of absence must always depend upon the calls of duty, to which pleasure or study must equally yield.

Lord Panmure will not be indisposed to consider the case of the medical officers, in respect to the length of service which gives a claim for retirement; but upon this point, as well as the general propositions following, his Lordship can give at present no other reply than that they shall receive fair consideration, in any change of the medical department that may take place.

The complaint of the memorialists on the introduction of civil practitioners to posts of authority and emolument created by the necessities of the war, is, in the opinion of Lord Pan- mure, entirely uncalled for. The ranks of the Military Medical Department were totally anable to supply the extensive hospitals created in the East. These establishments were only temporary. It would have been unwise and improvident to have based on them an increase of permanent establishments, to become a burden to the country in after years. The comparatively high pay of the civil practitioners appointed to these hospitals, many of whom gave up valuable private practices at the call of humanity, is based entirely upon the temporary nature of their services, and can furnish no ground for complaint that the regular department has been overlooked.

I am, \&c.,

G. C. MUNDY.

Dr. Andrew Smith, Director-General of Hospitals.

\section{TRIAL FOR SLOW POISONING AT DURHAM.}

The following is the summing-up of Mr. Baron Martin of the evidence adduced against Mr. Wooler, for the murder of his wife:-

The learned JUDGr summed up with some masterly observations upon the case and the evidence. He observed that the accusation against the prisoner was, that by continued small doses of arsenic he poisoned his wife, and in case of conviction he would undoubtedly forfeit his life. Much has been said about prejudice in this case, but, observing your calm demeanour and attention, I should not have observed upon it, except for an exhibition of feeling on Saturday. That deceased died by arsenic was early in this trial admitted by the prisoner's connsel. The next question is, whether there is sufficient evidence to show that the prisoner administered it? In most cases of murder certain facts are clearly established, from which, although circumstantial only, juries may safely draw conclusions. This is the first case of poisoning extending over so long a period. The law requires that the conclusions of $\mathbf{a}$ jury should be drawn from proximate and evident premises, not from slight and far-fetched surmises. I have collected the circumstances which the learned counsel for the prosecution relies on to prove that the prisoner is guilty. If you have read his speech, I pray you not to rely on it, but on the evidence. It is clear that the prisoner had a large collection of drugs in his possession. Dr. Jackson and Dr. Haslewood state that Fowler's solution was among them. At the inquest it is said that this bottle was not produced, but no importance appears to have been then attached to the circumstance. It does not appear but that, if the prisoner had been asked about it, he could have produced it, or given an explanation of it. The next circumstance relied on was, that the prisoner had not furnished proper medical advice for his wife. Of that you most judge. Having called in Dr. Jackson, he finds fault with him. [Here the learned Judge recapitulated the evidence on this head.] The next matter urged was that the prisoner kept a book in which he entered his wife's symptoms. We may assume that no entry appears to make against him, or it would have been read. But, indeed, Dr. Haslewood fully explained all about this book. The next matter is very important. It is that the doctors having desired the prisoner to communicate to them the tingling of the hands, if it should occur, he omitted to do so. Upon this point the counsel for the prosecution has been misinstructed. Dr. Jackson and Dr. Haslewood say they never so requested the prisoner to inform them of this, neither do they agree as to the exact time or manner in which the prisoner did communicate the circumstance. [Here the learned Judge read their evidence on this subject.] The learned counsel for the prisoner has spoken in harsh terms of the medical witnesses. I do not adopt those terms, but it does seem to me that their conduct, as detailed by themselves, was reprehensible. But people are often wise after the event, and I believe that those witnesses now think that their suspicinns were stronger at the time than they really were. Why did they not sooner find out this symptom of tingling of the hands, by asking Mrs. Wooler herself? If they suspected that arsenic was being administered, they should have gone before a magistrate, instead of simply using twice an antidote. The learned judge commented severely upon Dr. Jackson's statement, that he had withheld from Dr. Haslewood his suspicions. I think that Mr. Henzell was the first to suspect, and that the others did not pay much attention to his suspicions. The supposed substitution of another person's urine might have been a mistake. The conduct of the prisoner at the time of his wife's death is said to have been improper. You have evidence on this head, on which you must form your own opinion. But I 